\title{
Seasonal response of Posidonia oceanica epiphyte assemblages to nutrient increase
}

\author{
Patricia Prado $^{1, *}$, Teresa Alcoverro ${ }^{1}$, Javier Romero ${ }^{2}$ \\ ${ }^{1}$ Centro de Estudios Avanzados de Blanes, c/ Accés a la Cala St. Francesc, 14, 17300 Blanes, Girona, Spain \\ ${ }^{2}$ Departamento de Ecología, Facultad de Biología, Universidad de Barcelona, Avda. Diagonal 645, 08028 Barcelona, Spain
}

\begin{abstract}
The effect of nutrient availability on epiphyte assemblages on the leaves of the seagrass Posidonia oceanica was investigated in an oligotrophic meadow, paying attention to the species composition. The experiment consisted of a year-long monthly column water nutrient addition experiment. Nutrient additions resulted in modest effects on epiphytic biomass (increases only detected in August and September), but in large modifications in the structure of epiphytic assemblages from June to September, with an initial decrease in bryozoan cover (Electra posidoniae) and a stimulation of phaeophytes (Sphacelaria cirrosa, Dictyota spp.) and some Ceramiaceae in summer months. Other variables, such as epiphyte cover, epiphyte nitrogen content, and the algal epiphyte to zooepiphyte ratio also responded to nutrient enrichment during summer, but showed different responses depending on epiphyte composition. In contrast, winter assemblages, largely represented by zooepiphytes and encrusting algae, did not respond in any way to the nutrient treatment. Results support the notion that in oligotrophic temperate systems epiphyte community composition is controlled by nutrient availability from late spring to the end of summer, not only in quantitative, but also in qualitative terms.
\end{abstract}

KEY WORDS: Posidonia oceanica · Nutrient enrichment · Algal epiphytes · Zooepiphytes · Seasonality · Assemblage composition · Univariate measures

\section{INTRODUCTION}

Epiphyte communities contribute substantially to primary production of seagrass ecosystems (Morgan \& Kitting 1984), represent a significant part of their biodiversity, and participate in important functional aspects such as food and habitat supply for animal communities (Mazzella et al. 1992, Jernakoff et al. 1996), carbon and nutrient deposition (Gacia et al. 2002) and seagrass shading (Dalla Via et al. 1998). Hence, this recognition of the important role of epiphytes in ecosystem functioning has stimulated research on factors controlling the overall biomass abundance. Among them, light (Dalla Via et al. 1998), temperature (Neckles et al. 1993), salinity (Kendrick et al. 1998) and nutrients (Frankovich \& Fourqurean 1997) have been identified as the most important. Surprisingly, considering its relevance, much less atten- tion has been paid to what controls the taxonomic composition of the epiphytic community (but see Borum et al. 1984, Frankovich \& Fourqurean 1997). Variability in the importance of epiphyte effects has been largely associated to biomass variability, but it is most likely that epiphyte-mediated processes within seagrass beds are determined by the relative abundance of species and the existence of functional groups that provide specific ecosystem services. Epiphyte composition (e.g. encrusting versus erect forms) may considerably affect shading (Sand-Jensen 1977), thus having a great influence on the vitality of the seagrass host. Similarly, biogeochemical processes such as nitrogen fixation (Goering \& Parker 1972) and recycling of calcium carbonate (Walker \& Woelkerling 1988) are accomplished by specific taxa. Complex interactions may also arise from the synthesis of chemical and structural compounds (Hay 1996) and/or algal morphology (Gacia et 
al. 1999), and may account for specialised feeding habits of certain grazers and for the resulting dynamic shaping of communities (Mazzella \& Russo 1989, Jernakoff \& Nielsen 1997).

Along with biomass patterns, changes in epiphyte composition are thought to be largely regulated by nutrient availability, especially in oligotrophic waters. Unlike seagrasses that have 2 complementary sources of nutrients (i.e. water column and sediment pore water), algal epiphytes are highly dependent on water column nutrients (Williams \& Ruckelshaus 1993). Consequently, a direct relation between seasonal fluctuations in water nutrient availability and epiphyte biomass and composition (Borum et al. 1984, Frankovich \& Fourqurean 1997, Wear et al. 1999) is expected. However, it is often neglected that epiphyte communities consist of heterogeneous assemblages of both autotrophic and heterotrophic organisms (e.g. bryozoans, hydrozoans, ascidians, foraminifers) that may have different environmental requirements. Further, changes in the feeding behaviour of grazers may be able to control alterations in the epiphyte communities induced by nutrients (Neckles et al. 1993, Williams \& Ruckelshaus 1993, Hays 2005).

Epiphytes on Posidonia oceanica, the dominant seagrass species in the oligotrophic Mediterranean, have been reported to change seasonally (Mazzella \& Ott 1984, Ballesteros 1987), but the influence of continuous nutrient supply on the dynamic seasonal succession in community composition has not been properly investigated. The distinct seasonality in nutrient limitation in the Mediterranean (Ballesteros 1992, Alcoverro et al. 1997a) is effectively mirrored by seagrasses (Pérez et al. 1991, Invers et al. 2002) and most likely plays a crucial role in structuring epiphyte communities, since the latter are unable to store nutrients during unfavourable periods and, therefore, have a higher dependence on water column nutrients than the plant. Other seasonally important processes, such as herbivory (Prado et al. 2007), have been shown to exert an important control on epiphyte biomass (Alcoverro et al. 1997b) and composition by preferentially removing certain macroalgal species (Mazzella \& Russo 1989, Jernakoff \& Nielsen 1997). If nutrients exert such control on epiphyte communities, we should expect to observe a significant response to enrichment, either in terms of increased biomass or in changes in epiphyte composition.

In the present study, we experimentally tested the hypothesis that nutrients may not only modify epiphyte loads (i.e. biomass and leaf cover), but also exert an important control on the structure of the seagrass epiphytic community, including species richness, diversity and species composition. In particular, we conducted detailed examination of the response of epiphyte assemblages to nutrient availability and how these potential changes interact with the natural cycles of nutrient availability. To this end, we conducted a yearlong nutrient addition experiment in a meadow of Posidonia oceanica (L.) Delile living in oligotrophic conditions, and we assessed all the above-mentioned changes in the epiphytic communities.

\section{MATERIALS AND METHODS}

Study site and experimental design. The study was conducted in an exposed area off Fenals cove, on the northeastern Mediterranean Spanish coast $\left(41^{\circ} 41^{\prime} \mathrm{N}\right.$, $\left.003^{\circ} 18^{\prime} \mathrm{E}\right)$. Water temperature usually oscillates seasonally from 13 to $23^{\circ} \mathrm{C}$ (Cebrián et al. 1996a), although the summer of the sampling period was exceptionally hot (up to $26^{\circ} \mathrm{C}$ in July). The area also features relatively low mean annual levels of nutrients in the water column $(0.96 \pm 0.07 \mu \mathrm{M}$ for nitrate and $0.29 \pm$ $0.04 \mu \mathrm{M}$ for phosphate; Cebrián et al. 1996a).

The experiment was carried out in a shallow $(8 \mathrm{~m}$ depth) Posidonia oceanica meadow, in which vegetated and sand patches alternate. We selected 12 seagrass patches of equivalent area (ca. $3 \mathrm{~m}^{2}$ ) that were at least $10 \mathrm{~m}$ apart from each other, and randomly assigned 6 of them to the enrichment treatment, and the remaining to controls. Each month 6 shoots plot ${ }^{-1}$ (mean meadow density of $1050 \pm 112$ shoots $\mathrm{m}^{-2}$ ) were collected adjacent to randomly placed nutrient containers (see next section) prior to each new fertilization treatment. We conducted this design because we specifically wanted to assess the importance of seasonality in the effect of the nutrient supply to epiphytic assemblages. In fact, species turnover following seasonal factors (e.g. plant growth, herbivory, light, temperature, nutrient availability and hydrodynamics) has been indicated as the most important factor driving the structure and assemblage composition in P. oceanica (e.g. Mazzella \& Ott 1984, Ballesteros 1987, Alcoverro et al. 1997b). This seasonality suggests the undergoing of a natural 'reset' of epiphyte species, which, in our experiment, was enhanced by water flux conditions. In addition, other local variables such as large plot size and high shoot density were expected to prevent conditions dependent on previous periods of enrichment (i.e. autocorrelation between sampling months; see 'Data analyses').

Nutrient additions and sample processing. After preliminary nutrient release tests in the laboratory, we used both a mixture of di-potassium hydrogen phosphate anhydrous, sodium nitrate and ammonium chloride (Panreac) salts and Osmocote universal (ratio N/P/K 14:13:13) as fertilizers. Nutrient salts were mixed with fine sand $(50 \%$ nutrient salts, one- 
third each, and $50 \%$ sand) and placed in plastic containers $(200 \mathrm{ml})$, whereas the Osmocote fertilizer was simply filled into containers. The cylindrical external face of the containers was perforated up to 20 times ( $2 \mathrm{~mm}$ hole diameter) to allow nutrient release. This method produced a large release of nutrients during 1 wk (the salt mixture; authors' pers. obs.), but also allowed continuous release during a whole month (the Osmocote; Heck et al. 2000). In the field, water nutrient enrichment was performed monthly after sample collection for $1 \mathrm{yr}$ (in November, January and February enrichment was done, but no samples were collected, since no changes were detected in previous months and changes in environmental factors during winter are minor; Cebrián et al. 1996b), using a combination of 6 salt and 3 osmocote containers randomly placed within each plot. No decreased water clarity in the form of either particulate matter or phytoplankton blooms was observed in or near the plots.

Three of the 6 collected shoots (per plot) were used for epiphyte identification; only the oldest leaf was examined as representative of the shoots' epiphytic and sessile epifaunal assemblages (Vanderklift \& Lavery 2000, Ballesteros pers. comm.). Nevertheless, in instances where the oldest leaf was too short (i.e. $<10 \mathrm{~cm}$ ), the second oldest leaf was also considered, to ensure that equivalent leaf areas in all shoots were examined. A cover of $0.1 \%$ was assigned to rare and small species (erect or prostrated filaments on the order of $10 \mathrm{~s}$ to $100 \mathrm{~s}$ of micrometres) that were found only once per replicate leaf, according to standard practice (e.g. Ballesteros 1987, Cormaci et al. 2004, Cebrian \& Ballesteros 2004). For encrusting (e.g. Myrionema magnusii and Hydrolithon spp.) and seasonally abundant epiphytes (e.g. Electra posidoniae and Spacelaria cirrosa), cover was determined under the microscope, through visual estimation of the proportion of the leaf stratum used by each species. For the remaining, less abundant species for which estimation of cover required previous detachment from the leaf stratum with a razor blade, values from $0.2 \%$ were assigned by comparison with the $0.1 \%$ criteria (see Appendix 1, Electronic Supplement, available at www.int-res.com/journals/suppl/m359p089_app.pdf).

Species richness was calculated as the total number of species recorded growing on the oldest leaf of each shoot and the alga/animal ratio as the quotient between the percentage cover of total algal epiphytes and that of zooepiphytes.

Species diversity was estimated from the Shannon index such that:

$$
H=-\sum_{i=1}^{s} p_{i} \log p_{i}
$$

where $s$ is the number of species and $p_{i}$ is the proportion of the epiphytic leaf cover belonging to species $i$.

The 3 remaining shoots were used to determine leaf length and width, and the presence of bite marks (fish or sea urchin) or broken apices. Epiphytes were then removed with a razor blade and leaves and epiphytes were dried at $60^{\circ} \mathrm{C}$ for $48 \mathrm{~h}$, weighed separately, and ground to a fine powder with a mortar. These samples were analysed with an EA 1108 CHNS-O Carlo Erba Analyser (Serveis Científico-Tècnics, Universitat de Barcelona) to determine their nitrogen and carbon content.

Data analyses. Univariate analyses: The influence of nutrient treatment (fixed factor), plot (random factor) and month (fixed factor) on species richness, alphadiversity, epiphytic biomass and epiphyte $\mathrm{N}$ content (dependent variables) was assessed with a 3-way ANOVA (results from time-series analyses showed the absence of autocorrelation for all epiphytic variables; see above). Treatment was orthogonal with month, and plot was nested within treatment. Plant features (length of the oldest leaf and $\mathrm{N}$ content) were, however, investigated separately for month (1-way ANOVA) and treatment effects (2-way ANOVA; plot nested within treatment), since significant autocorrelation was found among sampling periods. ANOVA assumptions of homogeneity of variances and normality were tested by Cochran's test and KolmogorovSmirnov distribution-fitting test of the residuals, respectively. Appropriate transformations were used when necessary to correct deviations from ANOVA assumptions. For all analyses, the critical level of significance was fixed at $\mathrm{p}<0.05$. Student-NewmanKeuls (SNK) post hoc comparisons were used to identify significant differences between treatments at each month of sampling.

Multivariate analyses: Patterns of spatial and temporal variation in epiphytic assemblages were investigated using the PRIMER software package from Plymouth Marine Laboratory (UK). Leaf cover values for each species were square-root-transformed prior to analysis and then used to build a Bray-Curtis (BC) dissimilarity matrix. Non-metric multidimensional scaling (n-MDS) was applied to examine the influence of month and treatment in the structure of epiphyte assemblages. Analysis of similarities (ANOSIM) was also conducted to test whether differences in species composition and abundance observed in n-MDS results were significant. As ANOSIM does not allow testing for $>2$ factors, we first conducted a 2-way nested ANOSIM to test for monthly differences between treatments and among plots. A separated 2-way orthogonal analysis was conducted to test for differences between treatments and among months. 


\section{RESULTS}

\section{Epiphytic taxa}

A total of 114 epibiontic taxa were found over all months and treatments (see Appendix 1 at www. int-res.com/articles/suppl/m359p089_app.pdf for a detailed list of all species encountered during the study). Taxa included: diatoms (tube dwelling species), cyanobacteria (2 species), Rhodophyta (57 taxa), Phaeophyta (15 taxa), Chlorophyta (8 taxa), hydrozoans (15 species), bryozoans (13 taxa), ascidians (2 species) and 1 kamptozoan (Entoprocta) and were similar to those previously reported to occur seasonally in the same area (Ballesteros 1987, García-Rubies 1987).

\section{Univariate analyses}

Species richness

Monthly differences were the most important source of variation in species richness. Minimum values were observed after leaf fall in October $(4.3 \pm 1$ species leaf $\left.^{-1}\right)$ and were maximum in May $(16.6 \pm 2.4$ species leaf $^{-1}$ in May 2004), when the typical spring community of Giraudia sphacelariodes and Cladosiphon spp. develops. However, from June to September 2003 (i.e. the summer period) and then again in June 2004, enrichment caused a significant increase in the number of species per leaf $(16.3 \pm 1.8$ and $8.4 \pm 1.9$ species leaf $^{-1}$ in nutrient and control plots, respectively; Table 1, SNK $;$ p 0.05; Fig. 1A). This difference was largely due to an enhanced presence of small, occasional red algae, particularly Ceramiaceae.

\section{Alpha diversity}

This index showed similar monthly patterns of variation to those described for species richness. Signifi- cantly higher values of diversity were detected in nutrient plots from June to September 2003 and in June 2004 (mean values for that period of ca. $1.6 \pm 0.2$ and $0.9 \pm 0.2$ in nutrient and control plots, respectively; Table 1, SNK $; \mathrm{p}<0.05)$. However, a relative decrease in diversity was also observed in both treatments in August to September due to the dominance of a few macroalgal species (i.e. Sphacelaria cirrosa, Dictyota spp.; Fig. 1B) during those months.

\section{Leaf cover}

Minimum monthly values were detected in October $2003(35.3 \pm 6.2 \%)$ due to seasonal leaf fall and the presence of a few pioneer species (e.g. Fosliella spp., Myrionema magnusii and the zooepiphytes Sertularia perpusilla and Electra posidoniae), while maximum cover values were registered in May $(95 \pm 2.4 \%)$, coinciding with the largest animal abundance $(S$. perpusilla and E. posidoniae) and the development of an algal epiphyte community formed by Sphacelaria cirrosa, Giraudia sphacelariodes, Cladosiphon spp. and Ectocarpaceae, among others. In June 2003, nutrients caused a significant decrease in cover $(63.8 \pm 4.3$ and $84.9 \pm 4.9 \%$, enriched and control, respectively; Table 1, SNK $;$ p $<0.05 ;$ Fig. 1C) due to greater decline of the bryozoan Electra posidoniae. In contrast, the opposite trend was observed in August to September $(85.5 \pm 6.2$ and $43.4 \pm 6.3 \%$ leaf cover in nutrient and control plots, respectively; Table 1, $\mathrm{SNK}_{i} \mathrm{p}<0.05$; Fig. 1C), resulting from enhanced development of the $S$. cirrosa and Dictyota spp. in nutrient plots.

\section{Biomass}

Month was by large the main source of variation, with minimum values in October $2003(0.016 \pm 0.002)$ and a peak in May 2003 and 2004 (0.18 \pm 0.024$)$, result-

Table 1. Results of 3-way ANOVA for epiphytic variables: species richness, alpha diversity, leaf cover, epiphyte biomass, alga/animal ratio and $\mathrm{N}$ content. Significant differences are indicated in bold. Transf.: type of data transformation; $C$ : Cochran's $C$

\begin{tabular}{|c|c|c|c|c|c|c|c|c|c|c|c|c|c|c|c|c|c|c|c|}
\hline \multirow[t]{2}{*}{$\begin{array}{l}\text { Source of } \\
\text { variation }\end{array}$} & \multirow[t]{2}{*}{$\mathrm{df}$} & \multicolumn{3}{|c|}{$\begin{array}{l}\text { Species } \\
\text { richness }\end{array}$} & \multicolumn{3}{|c|}{$\alpha$-Diversity } & \multicolumn{3}{|c|}{ Cover } & \multicolumn{3}{|c|}{$\begin{array}{l}\text { Epiphytic } \\
\text { biomass }\end{array}$} & \multicolumn{3}{|c|}{$\begin{array}{l}\text { Alga/animal } \\
\text { ratio }\end{array}$} & \multicolumn{3}{|c|}{$\begin{array}{c}\mathrm{N} \text { in } \\
\text { epiphytes }\end{array}$} \\
\hline & & MS & F & $\mathrm{p}$ & MS & $F$ & $\mathrm{p}$ & MS & $F$ & $\mathrm{p}$ & MS & F & $\mathrm{p}$ & MS & F & $\mathrm{p}$ & MS & $F$ & $\mathrm{p}$ \\
\hline Treatment $=\mathrm{T}$ & 1 & 1550 & 314.58 & 0.000 & 14.088 & 237.75 & 0.000 & 4359 & 139.02 & 0.000 & 0.0027 & 17.11 & 0.002 & 95871 & 952.16 & 0.000 & 0.171 & 2.28 & 0.162 \\
\hline Plot = P (T) & 10 & 4.9 & 1.93 & 0.042 & 0.059 & 1.4 & 0.180 & 31 & 1.03 & 0.419 & 0.0002 & 0.66 & 0.765 & 101 & 1.17 & 0.310 & 0.007 & 1.72 & 0.076 \\
\hline Month $=$ M & 9 & 559.7 & 151.48 & 0.000 & 14.682 & 254.25 & 0.000 & 10351 & 227.66 & 0.000 & 0.1888 & 990.24 & 0.000 & 67629 & 840.64 & 0.000 & 18.843 & 271.60 & 0.000 \\
\hline $\mathrm{T} \times \mathrm{P}(\mathrm{T})$ & & - & - & - & - & - & - & - & - & - & - & - & - & - & - & - & - & - & - \\
\hline $\mathrm{T} \times \mathrm{M}$ & 9 & 150.7 & 40.77 & 0.000 & 1.360 & 23.55 & 0.000 & 3645 & 80.17 & 0.000 & 0.0059 & 30.78 & 0.000 & 40748 & 506.51 & 0.000 & 1.028 & 14.81 & 0.000 \\
\hline $\mathrm{P}(\mathrm{T}) \times \mathrm{M}$ & 90 & 3.7 & 1.45 & 0.014 & 0.058 & 1.36 & 0.032 & 45 & 1.49 & 0.008 & 0.002 & 0.81 & 0.882 & 80 & 0.94 & 0.634 & 0.069 & 1.59 & 0.003 \\
\hline \multirow[t]{2}{*}{$\mathrm{T}(\mathrm{T}) \times \mathrm{P} \times \mathrm{M}$} & & - & - & - & - & - & - & - & - & - & - & - & - & - & - & - & - & - & - \\
\hline & & \multicolumn{3}{|c|}{ Transf: $-; C=0.10$} & \multicolumn{3}{|c|}{ Transf: $-; C$} & \multicolumn{3}{|c|}{ Transf: $-; C=0.04$} & \multicolumn{3}{|c|}{ Transf: $x_{i} C=0.08$} & \multicolumn{3}{|c|}{ Transf: -; } & \multicolumn{3}{|c|}{ Transf: $-; C=0.09$} \\
\hline
\end{tabular}


ing from higher leaf cover by the bryozoan Electra posidoniae and the hydrozoan Sertularia perpusilla. A significant interaction effect was also found due to enhanced epiphyte biomass (Sphacelaria cirrosa and, to a lesser extent, Dictyota spp.) in nutrient plots during August to September 2003 (0.06 \pm 0.009 and $0.013 \pm 0.005 \mathrm{~g} \mathrm{shoot}^{-1}$ in nutrient and control plots, respectively; Table 1, SNK; $\mathrm{p}<0.05$; Fig. 1D).

\section{Alga/animal ratio}

Maximum values occurred from August to September $(179.8 \pm 22.5$, Fig. $1 \mathrm{E})$, due to high abundance of algal epiphytes (mainly Sphacelaria cirrosa and Dictyota spp.), whereas minimums were registered in March to May (ca. $32.4 \pm 9.1$, Fig. 1E) when animal cover (the bryozoan Electra posidoniae) was the
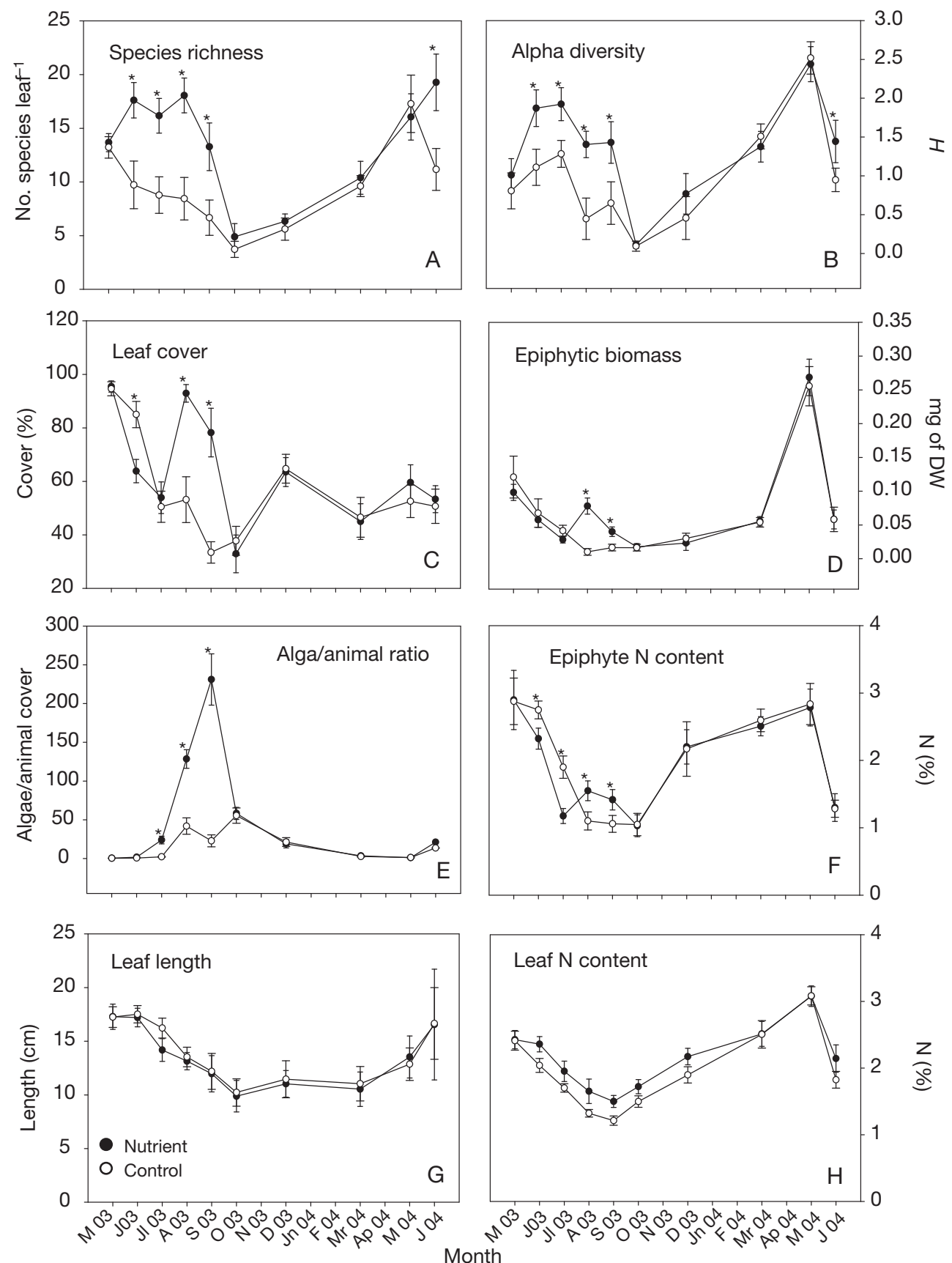

Fig. 1. Monthly trends in (A) species richness, (B) alpha diversity, (C) leaf cover, (D) epiphyte biomass, (E) alga/animal ratio, (F) epiphyte N content, $(\mathrm{G})$ leaf length and $(\mathrm{H})$ nitrogen content of Posidonia oceanica in nutrient and control plots. Asterisks indicate significant differences between treatment groups (SNK post hoc comparisons). Error bars are SE 
largest. Enrichment caused an increase in the dominance of algal epiphytes from July to September $(127.9 \pm 16.7$ and $22.4 \pm 6.2$ in nutrient and control plots, respectively; Table 1, SNK; $\mathrm{p}<0.05$; Fig. 1E). The increase in the abundance of $S$. cirrosa accounted for most of these differences (see above, 'Biomass').

\section{Nitrogen in epiphytes}

The highest values were in October $(1 \pm 0.2 \%)$ and the lowest in May $(2.8 \pm 0.3 \%)$. Enrichment caused significant differences between treatments throughout the summer period (Table 1, SNK $; \mathrm{p}<0.05 ;$ Fig. 1F). In June to July, lower animal abundance in nutrient plots caused higher $\mathrm{N}$ content in nutrient $(1.7 \pm 0.1 \%)$ control plots $(2.3 \pm 0.1 \%)$. This trend was reversed in August to September, following the dominance of macroalgal epiphytic communities in both treatments $(1.5 \pm 0.1$ and $1.1 \pm 0.2 \%$ in nutrient and control plots, respectively).

\section{Length of oldest leaf}

Monthly differences were generally significant, with shorter leaves during leaf fall in October 2003 (10 \pm $1.4 \mathrm{~cm}$ ) and longer leaves during the period of highest annual productivity in May-June $2003(17.3 \pm 0.9 \mathrm{~cm})$. Enrichment caused a slightly significant reduction in leaf length (Table 2), possibly due to enhanced fish herbivory in July (see Fig. 1G), which mostly affected intermediate leaves (Prado 2007).

\section{Nitrogen content in Posidonia oceanica}

Monthly values followed typical seasonal patterns of variability, with highest contents in May (3.1 $\pm 0.1 \%)$ and lowest in September to October (1.3 $\pm 0.07 \%$; Table 2). Enrichment also caused significant increase in the leaf $\mathrm{N}$ content $(2.2 \pm 0.03$ and $1.9 \pm 0.04 \%$ in

Table 2. Posidonia oceania. Results of 1-way and 2-way ANOVA testing for differences in plant variables: leaf length and leaf N content. Significant differences are indicated in bold. Transf.: type of data transformation; $C$ : Cochran's $C$

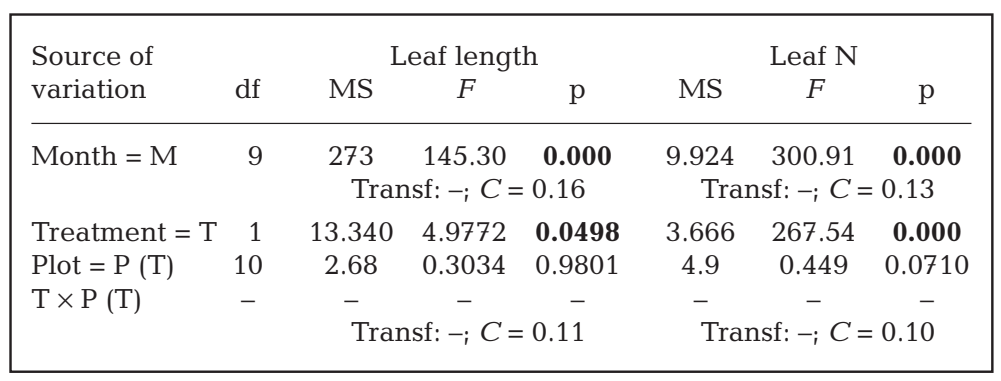

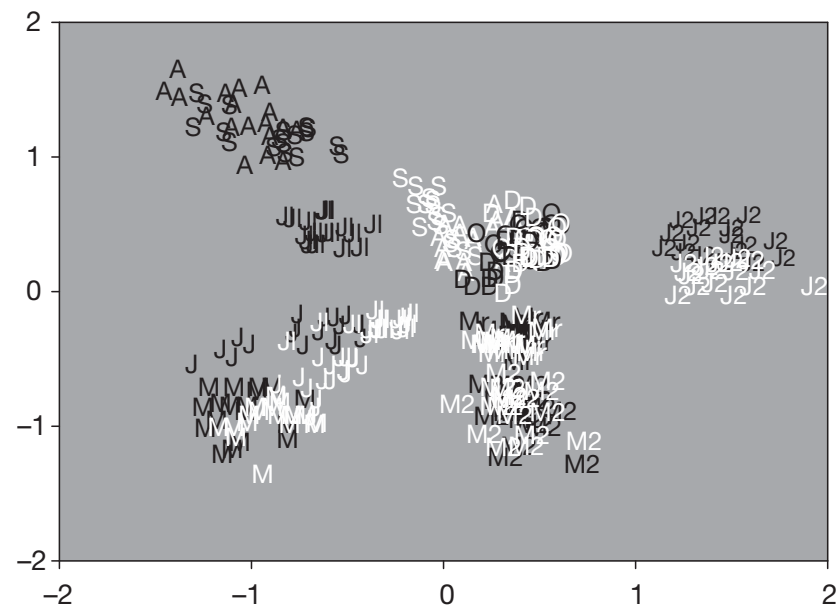

Fig. 2. n-MDS ordination showing differences found between months and treatments. $\mathrm{M}=$ May 2003; $\mathrm{J}=$ June 2003, $\mathrm{Jl}=$ July 2003; A = August 2003; S = September 2003, O = October 2003; D = December 2003; Mr = March 2004; M2 = May 2004; $\mathrm{J} 2$ = June 2004. Nutrient treatments are displayed in black, and control in white

nutrient and control plots, respectively; Table 2) during most of the year (i.e. June to December 2003 and then again in June 2004; see Fig. 1H).

\section{Multivariate analyses}

Posidonia oceanica epiphyte assemblages were tightly controlled by month effects and, to a lesser extent, by nutrient influences (2-way crossed ANOSIM, $\mathrm{R}=0.875, \mathrm{p}=0.001$ and $\mathrm{R}=0.259, \mathrm{p}=0.001$ for month and between-treatment effects, respectively). As for univariate measures, the clearest separation of enriched and control samples occurred in the summer months, which clustered in the upper left quadrant of the plot, whereas, at other times of the year, samples appear to group more strongly according to month than by treatment (see Fig. 2). In fact, the response of the communities started 1 mo after the initiation of the experiment (May 2003) and persisted until September (i.e. Global R values close to 1$)$, to disappear in fall and winter and reappear again the following spring (May and June 2004; see Table 3). Amongplots variation was generally small (i.e. Global R values close to zero), but showed significance in all months except October 2003 and May 2004. However, if certain of these values indicate a certain degree of patchiness, they were close to the values that Clarke \& Warwick (1994) proposed as indicative of negligible biological difference. Generally, for all n-MDS ordinations, low stress values indicated a good overall representation of assemblage patterns. 
Table 3. Results of 2-way nested ANOSIM based on dissimilarity matrices derived from leaf cover values of epiphyte species (square root transformation). Differences among replicate plots and differences between treatments in each month of the experiment are shown. Significant differences are indicated in bold. R: ANOSIM statistic; p: significance level of sample statistic (\%)

\begin{tabular}{|lcccc|}
\hline & \multicolumn{2}{c}{ Within treatments } & \multicolumn{2}{c|}{$\begin{array}{r}\text { Between treatments } \\
\text { R statistic }\end{array}$} \\
& R statistic & $\mathrm{p}$ & & \\
\hline May 2003 & 0.20 & $\mathbf{0 . 3}$ & 0.017 & 38.5 \\
Jun 2003 & 0.386 & $\mathbf{0 . 1}$ & 0.885 & $\mathbf{0 . 2}$ \\
Jul 2003 & 0.360 & $\mathbf{0 . 1}$ & 1 & $\mathbf{0 . 2}$ \\
Aug 2003 & 0.175 & $\mathbf{1 . 1}$ & 1 & $\mathbf{0 . 2}$ \\
Sep 2003 & 0.194 & $\mathbf{0 . 3}$ & 1 & $\mathbf{0 . 2}$ \\
Oct 2003 & 0.137 & 7.6 & 0.209 & $\mathbf{4 . 8}$ \\
Dec 2003 & 0.176 & $\mathbf{1 . 4}$ & 0.006 & 41.1 \\
Mar 2004 & 0.136 & $\mathbf{3 . 1}$ & 0.061 & 18.6 \\
May 2004 & 0.09 & 7.9 & 0.454 & $\mathbf{0 . 2}$ \\
Jun 2004 & 0.176 & $\mathbf{0 . 9}$ & 0.764 & $\mathbf{0 . 2}$ \\
& & & & \\
\hline
\end{tabular}

\section{DISCUSSION}

Nutrient enrichment caused noticeable alterations in the epiphytic community inhabiting the leaves of Posidonia oceanica, but only in late spring and summer. Differences included increased species richness, diversity, biomass, cover and epiphyte nutrient content, but also a drastic change in the taxonomic composition of epiphyte assemblages. This indicates the strong and direct dependence of epiphytic community on water nutrient availability, not just in quantitative terms, as has been previously documented (Williams \& Ruckelshaus 1993, Frankovich \& Fourqurean 1997, Drake et al. 2003), but also in terms of qualitative and structural properties, at least during certain periods.

The results obtained during the period ranging from late spring until late summer confirm previous findings (Wear et al. 1999, Hillebrand 2003) that experimental addition of nutrients may cause an increase in both species richness and diversity. Such patterns were due to the high abundance of filamentous macroalgae (Ceramiaceae), which however made little contribution to total epiphyte loads. In fact, epiphytic biomass only increased in August to September by the growth of a few ephemeral species that spread over the leaves in nutrient plots and dominated the community. Under conditions of increased nutrient availability, the development of fast-growing macroalgae is usually stimulated, since they have higher demands of nutrients per biomass unit (Pedersen \& Borum 1996). However, this takes place only when other factors or resources, such as light and temperature, are at their optima, thus explaining the pattern of higher biomass values in early spring, before nutrients become limiting (Jacobs et al. 1983, Borum et al. 1984).
Monthly enrichment was not able to disrupt the patterns of seasonal succession identified in earlier studies (Mazzella \& Ott 1984, Ballesteros 1987, Alcoverro et al. 1997b), thus confirming the overriding influence of seasonal factors such as herbivory, light, temperature, nutrients and hydrodynamics in assemblage structure. In winter, the Posidonia oceanica epiphyte community is dominated by hydrozoans, bryozoans and slow-growing, encrusting algae, and this winter assemblage remains unchanged despite the fertilising treatment. This is due to 2 main reasons. On the one hand, zooepiphytes are mostly suspension feeders, not directly affected by nutrients and generally showing different requirements than macroalgae in relation to environmental features such as light, temperature and hydrodynamics (Gili et al. 1984, Lippert et al. 2001). On the other hand, some encrusting coralline algae have relatively low nutrient and light demands (Dethier \& Steneck 2001), whereas winter conditions (i.e. low light and temperature) are probably unsuitable for fast-growing algae. In contrast, the response of such fast-growing algae occurred in spring to summer, when light conditions tend to favour growth but nutrients are scarce (Pedersen \& Borum 1996, Lotze et al. 1999). The sharp decrease in animal abundance in enriched plots between midspring and early summer (see Fig. 1E) is probably the consequence of algal overgrowth on the surfaces of leaves (i.e. nutrient-mediated competition; Ocito et al. 2001). Therefore, the bloom of Sphacelaria cirrosa appears to be caused by the coupling of nutrient availability and water temperature (or incident light), which can favour the germination of certain algae (Lotze et al. 1999) and enhance biomass growth in species close to $S$. cirrosa that have greater nutrient uptake rates than the plant and the remaining epiphytic community (Lepoint et al. 2004). In contrast, other potentially important variables in structuring assemblages, such as epiphyte consumption by small grazers (Neckles et al. 1993, Heck et al. 2000, Hays 2005), were probably of little influence on the results given that simultaneous assessment of mesoherbivore populations during the study indicated minimum annual abundances during the summer period due to post-hatching mortality and increased predation (Gacia pers. comm.). In contrast, a change in the grazing preferences of the fish Sarpa salpa was detected (Prado 2007), but since this species grazes mostly on intermediate shoot leaves (Cebrián et al. 1996b) and only the oldest leaves were used for the assemblage study, an influence on the observed patterns appears unlikely.

Our results have important implications for achieving a better understanding of the relationship between nutrients and epiphytes in seagrass ecosystems inhab- 
iting oligotrophic waters. For example, parameters such as epiphyte biomass or nutrient content have been used to detect or evaluate eutrophication (Frankovich \& Fourqurean 1997). Seagrass decline coinciding with nutrient discharge and epiphytic loads has been reported to occur permanently in other temperate systems (Cambridge et al. 1986, Moore et al. 1996). In the Posidonia oceanica ecosystem such univariate measures are, in general, good descriptors, but should be interpreted with some caution because of the significant mediating influence that seasonality wields on the power of detecting a nutrient response. Nutrient content of epiphytes responded to nutrient fertilization positively (August to September) or negatively (June to July 2003) depending on the period, because of the strong influence of seasonal changes in composition and the rapid species turnover. Epiphyte biomass was not substantially changed by nutrient enrichment, except in August, as most of the changes occurred at the level of species composition, and seasonal forcing (e.g. host dynamics, light temperature, nutrients and so on) was the main factor driving this variable. In contrast, epiphyte composition responds to nutrient enrichment unequivocally throughout the nutrient-limiting period (June to September), reinforcing the view that species composition is a much better epiphytic descriptor of eutrophication. The obvious caveat to this premise is that this difference is only detected in late spring to summer, when the extent of nutrient limitation is higher (Ballesteros 1992, Alcoverro et al. 1997a) and marine communities are more sensitive to changes in nutrient concentrations (Pérez et al. 1991, Invers et al. 2002). Importantly though, seasonality seemed to wield a weaker mediating influence on seagrass enrichment (presumably due to plant clonal growth), which may provide useful complementary information to address the time that lapsed after initiation of the nutrient input. In fact, the effect in the plant was long lasting (see also Frankovich \& Fourqurean 1997 for similar results), suggesting that seagrass nutrient content could be a more costeffective indicator of eutrophication. Conversely, knowledge of the assemblage's composition would be necessary to understand how nutrients may alter the functioning of the system, for example through grazing interactions induced by changes in the abundance of certain species or morphological groups (e.g. Gacia et al.1999, Thacker et al. 2001).

In summary, nutrient availability in the Posidonia oceanica seagrass meadow studied controls epiphytic assemblages from spring to autumn, while from fall to mid-spring other factors appear to influence community composition and abundance. The life period of epiphytes is completely determined by seagrass leaf fall, and does not allow species to employ long-term strategies like nutrient storage during the favourable periods. As a result, epiphyte communities display a quick response to nutrient supply and constitute an ideal indicator of nutrient availability during the period of nutrient limitation. No nutrient thresholds were identified in this study for detrimental interactions between epiphytes and the plant host. This will require a separate study with increased nutrient enrichments. Until this is achieved and considering the importance of nutrients on the control of $P$. oceanica epiphyte composition a cautious approach is recommended for the possible consequences of nutrient discharges in oligotrophic seagrass meadows.

Acknowledgements. We are very grateful to E. Ballesteros for his help with the identification of epiphytic algae and to $T$. García-Rubies for that of the zooepiphytes. We are also grateful to E. Gacia, B. Martinez, S. Mariani, F. Tomás and A. Vergés for field-work assistance throughout the experiment, and to R. Cortés and T. Thibaut for their help with deployment of nutrient containers. This work was supported by a FI scholarship from the Departament d'Universitats, Recerca I Societat de la Informació (DURSI, Generalitat de Catalunya) and the REN2002-04020/MAR project from the Spanish Ministry of Science and Technology.

\section{LITERATURE CITED}

Alcoverro T, Romero J, Duarte CM, López NI (1997a) Spatial and temporal variations in nutrient limitation of seagrass Posidonia oceanica growth in the NW Mediterranean. Mar Ecol Prog Ser 146:155-161

Alcoverro T, Duarte CM, Romero J (1997b) The influence of herbivores on Posidonia oceanica epiphytes. Aquat Bot 56: 93-104

Ballesteros E (1987) Estructura i dinamica del poblament algal de les fulles de Posidonia oceanica (L.) Delile als herbeis de Tossa de mar (Girona). Bull Inst Cat Hist Nat 54: $13-30$

Ballesteros E (1992) Els vegetals i la zonació litoral: èspecies, comunitats i factors que influeixen en la seva distribució. Institut d'Estudis Catalans, Seció de Ciències Biològiques II Collecció III, Fitogeografia Costa Brava, Barcelona

Borum J, Kaas H, Wium-Andersen S (1984) Biomass variation and autotrophic production of epiphyte-macrophyte community in a coastal Danish area. II. Epiphyte species composition, biomass and production. Ophelia 23: $165-179$

Cambridge ML, Chiffings AW, Brittan C, Moore L, McComb AJ (1986) The loss of seagrass in Cockburn Sound, Western Australia. II. Possible causes of seagrass decline. Aquat Bot 24:269-285

Cebrian E, Ballesteros E (2004) Zonation patterns of benthic communities in an upwelling area from the western Mediterranean (La Herradura, Alboran Sea). Sci Mar 68: $69-84$

Cebrián J, Duarte CM, Pascual J (1996a) Marine climate on the Costa Brava (Northwest Mediterranean) littoral. Publ Espec Inst Esp Oceanogr 22:9-21

Cebrián J, Duarte CM, Marbà N, Enríquez S, Gallegos M, Olesen B (1996b) Herbivory on Posidonia oceanica: magnitude and variability in the Spanish Mediterranean. Mar Ecol Prog Ser 130:147-155 
Clarke KR, Warwick RM (1994) Change in marine communities: an approach to statistical analysis and interpretation. Plymouth Marine Laboratory, Plymouth

Cormaci M, Furnari G, Giaccone G, Serrio D (2004) Alien macrophytes in the Mediterranean Sea: a review. Recent Res Dev Environ Biol 37/661:151-202

Dalla Via J, Sturmbauer C, Schönweger G, Sötz E, Mathekowitsch M, Stifter M, Rieger R (1998) Light gradients and meadow structure in Posidonia oceanica: ecomorphological and functional correlations. Mar Ecol Prog Ser 163: 267-278

> Dethier MN, Steneck RS (2001) Growth and persistence of diverse intertidal crusts: survival of the slow in a fastpaced world. Mar Ecol Prog Ser 223:89-100

Drake LA, Dobbs FC, Zimmerman RC (2003) Effects of epiphyte load on optical properties and photosynthetic potential of the seagrass Thalassia testudinum Banks ex König and Zostera marina L. Limnol Oceanogr 48:456-463

Frankovich TA, Fourqurean JW (1997) Seagrass epiphyte loads along a nutrient availability gradient, Florida Bay, USA. Mar Ecol Prog Ser 159:37-50

Gacia E, Littler MM, Littler DS (1999) An experimental test of the capacity of food web interactions (fish-epiphytes-seagrasses) to offset the negative consequences of eutrophication on seagrass communities. Estuar Coast Shelf Sci 48: $757-766$

Gacia E, Duarte CM, Middelburg JJ (2002) Carbon and nutrient deposition in a Mediterranean seagrass (Posidonia oceanica) meadow. Limnol Oceanogr 47:23-32

García-Rubies A (1987) Distribution of epiphytic hydroids on Posidonia sea grass. In: Bouillon J, Icogna FC, Ornelious PFSC (eds) Modern trends in the systematics, ecology and evolution of hydroids and hydromedusae. Oxford University Press, Oxford, p 143-155

Gili JM, García A, Colomer PL (1984) Els cnidaris bentònics de les Illes Medes. In: Ros J, Olivella I, Gili JM (eds) Els sistemes naturals de les Illes Medes. Institut d'Estudis Catalans, Barcelona, p 407-428

Goering JJ, Parker PL (1972) Nitrogen fixation by epiphytes on seagrasses. Limnol Oceanogr 17:320-323

> Hay ME (1996) Marine chemical ecology: What's known and what's next? J Exp Mar Biol Ecol 200:103-134

Hays CG (2005) Effect of nutrient availability, grazer assemblage and seagrass source population on the interaction between Thalassia testudimun (turtle grass) and its algal epiphytes. J Exp Mar Biol Ecol 314:53-68

Heck KL, Pennock JR, Valentine JF, Coen LD, Sklenar SA (2000) Effects of nutrient enrichment and small predator density on seagrass ecosystems: an experimental assessment. Limnol Oceanogr 45:1041-1057

Hillebrand $\mathrm{H}$ (2003) Opposing effects of grazing and nutrients on diversity. Oikos 100:592-600

Invers O, Perez M, Romero J (2002) Seasonal nitrogen speciation in temperate seagrass Posidonia oceanica (L.) Delile. J Exp Mar Biol Ecol 273:219-240

Jacobs RPWM, Hermelink PM, Van Geel G (1983) Epiphytic algae on eelgrass at Roscoff, France. Aquat Bot 15: $157-173$

Jernakoff P, Nielsen J (1997) The relative importance of amphipod and gastropod grazers in Posidonia sinuosa meadows. Aquat Bot 56:183-202

Jernakoff P, Brearley A, Nielsen J (1996) Factors affecting grazer-epiphyte interactions in temperate seagrass meadows. Oceanogr Mar Biol Annu Rev 34:109-162

Kendrick GA, Walker D, McComb AJ (1998) Changes in distribution of macro-algal epiphytes on stems of the seagrass Amphibolis antarctica along a salinity gradient in
Shark Bay, Western Australia. Phycologia 28:201-208

Lepoint G, Gobert S, Dauby P, Bouquegnau JM (2004) Contributions of benthic and planktonic primary producers to nitrate and ammonium uptake fluxes in a nutrient-poor shallow coastal area (Corsica, NW Mediterranean). J Exp Mar Biol Ecol 302:107-122

Lippert H, Iken K, Rachor E, Wiencke C (2001) Macrofauna associated with macroalgae in the Kongsfjord (Spitsbergen). Polar Biol 24:512-522

Lotze HK, Schramm W, Schories D (1999) Control of macroalgal blooms at early developmental stages: Pilayella littoralis versus Enteromorpha spp. Oecologia 119:46-54

Mazzella L, Ott J (1984) Seasonal changes in some features of Posidonia oceanica (L.) Delile leaves and epiphytes at different depths. In: Boudouresque CF, de Grissac AJ, Olivier $\mathrm{J}$ (eds) Proceedings of the international workshop on Posidonia oceanica beds, Vol 1. GIS Posidonie Publ, Marseilles, p 119-127

Mazzella L, Russo GF (1989) Grazing effect of two Gibbula species (Mollusca, Archaeogastropoda) on the epiphytic community of Posidonia oceanica leaves. Aquat Bot 35: $357-373$

Mazzella L, Buia MC, Gambi MC, Lorenti M, Russo GF, Scipione MB, Zupo V (1992) Plant-animal trophic relationships in the Posidonia oceanica ecosystem of the Mediterranean Sea: a review. In: John DM, Hawkins SJ, Price JH (eds) Plant-animal interactions in the marine benthos. Clarendon Press, Oxford, p 165-187

> Moore KA, Neckles HA, Orth RJ (1996) Zostera marina (eelgrass) growth and survival along a gradient of nutrients and turbidity in the lower Chesapeake Bay. Mar Ecol Prog Ser 142:247-259

Morgan MD, Kitting CL (1984) Productivity and utilization of the seagrass Halodule wrightii and its attached epiphytes. Limnol Oceanogr 29:1066-1076

> Neckles HA, Wetzel RL, Orth RJ (1993) Relative effects of nutrient enrichment and grazing on epiphyte-macrophytes (Zostera marina L.) dynamics. Oecologia 93: 285-295

Ocito SC, Gorbini SS, Erdeghini FF (2001) Seasonal and interannual growth variability of a bryozoan constructor. Arch Oceanogr Limnol 22:155-158

Pedersen MF, Borum J (1996) Nutrient control of algal growth in estuarine waters. Nutrient limitation and the importance of nitrogen storage among phytoplankton and species of macroalgae. Mar Ecol Prog Ser 142: 261-272

> Pérez M, Romero J, Duarte CM, Sand-Jensen K (1991) Phosphorus limitation of Cymodocea nodosa growth. Mar Biol 109:129-133

Prado P (2007) Magnitude of herbivory in Posidonia oceanica (L.) Delile and factors responsible for spatial variation. $\mathrm{PhD}$ thesis, University of Barcelona

Prado P, Tomas F, Alcoverro T, Romero J (2007) New evidence of the importance of herbivory on seagrass meadows: extensive direct measurements of Posidonia oceanica consumption in the continental Mediterranean coast. Mar Ecol Prog Ser 340:63-71

Sand-Jensen K (1977) Effect of epiphytes on eelgrass photosynthesis. Aquat Bot 3:55-63

> Thacker RW, Ginsburg DW, Paul JV (2001) Effects of herbivore exclusion and nutrient enrichment on coral reef macroalgae and cyanobacteria. Coral Reefs 19:318-329

- Vanderklift MA, Lavery PS (2000) Patchiness in assemblages of epiphytic macroalgae on Posidonia coriacea at a hierarchy of spatial scales. Mar Ecol Prog Ser 192:127-135

Walker DI, Woelkerling WJ (1988) Quantitative study of sedi- 
ment contribution by epiphytic coralline algae in seagrass meadows in Shark Bay, Western Australia. Mar Ecol Prog Ser 43:71-77

Wear DJ, Sullivan MJ, Moore A, Millie DF (1999) Effects of water-column enrichment on the production dynamics of

Editorial responsibility: Kenneth Heck Jr., Dauphin Island, Alabama, USA three seagrass species and their epiphytic algae. Mar Ecol Prog Ser 179:201-213

Williams SL, Ruckelshaus MH (1993) Effects of nitrogen availability and herbivory on eelgrass (Zostera marina) and epiphytes. Ecology 74:904-918

Submitted: June 28, 2006; Accepted: September 5, 2007

Proofs received from author(s): April 14, 2008 